\title{
ANALIZA TECHNICZNO-EKONOMICZNA HYBRYDOWEJ MIKROINSTALACJI SŁONECZNEJ
}

\begin{abstract}
Artykuł jest poświęcony analizie hybrydowej instalacji słonecznej. Publikacja dotyczy zarówno wytwarzania energii elektrycznej, jak i ciepła z energii promieniowania słonecznego. Największym problemem związanym z wytwarzaniem energii elektrycznej z energii słonecznej jest stosunkowo niska sprawność obecnie dostępnych ogniw fotowoltaicznych. Większość absorbowanej energii słonecznej jest konwertowana na ciepło, które jest tracone do otoczenia. Ciepło podwyższa temperaturę ogniw fotowoltaicznych. Ogniwa fotowoltaiczne mają tę własność, że im wyższa jest ich temperatura tym niższą osiągają sprawność. Aby rozwiązać ten problem odbiera się ciepło od ogniw fotowoltaicznych - takie rozwiązanie stosuje się w kolektorach hybrydowych PVT (ang. photovoltaic thermal).

W artykule opisany został model promieniowania słonecznego oraz model rozważanej instalacji. Jako wejściowe dane pogodowe wykorzystano temperaturę powietrza zewnętrznego, promieniowanie całkowite i jego składowe. Natężenie promieniowania półsferycznego padającego na płaszczyznę odbiornika o danej orientacji i pochyleniu było wyznaczane za pomocą modelu izotropowego promieniowania słonecznego dyfuzyjnego (model Liu-Jordana). Do zamodelowania kolektora hybrydowego PVT wykorzystano zmodyfikowany model Hottela-Whilliera-Blissa. Z przeprowadzonej analizy wynika, że instalacja PVT o mocy elektrycznej $2 \mathrm{kWp}$ może wytworzyć $1714 \mathrm{kWh}$ energii elektrycznej przez rok oraz $2359 \mathrm{kWh}$ ciepła przez rok. Zaprezentowane w artykule wyniki dowodzą, że układy hybrydowe PVT mogą być efektywnie stosowane w warunkach krajowych, jednak okres zwrotu nakładów inwestycyjnych jest dość długi (około 16 lat).
\end{abstract}

Słowa kluczowe: odnawialne źródła energii, energia słoneczna, fotowoltaika, instalacje hybrydowe

\section{Wprowadzenie}

Moduły fotowoltaiczne są szeroko rozpowszechnione i dostępne na rynku. W zależności od rodzaju osiągają sprawności konwersji energii promieniowani słonecznego na energię elektryczną od 5 do $20 \%$ (w warunkach standardowych) [1]. Obecnie dostępne na rynku moduły fotowoltaiczne to głównie modu-

\footnotetext{
1 Jarosław Bigorajski, Politechnika Warszawska, Instytut Techniki Cieplnej, Zakład Chłodnictwa i Energetyki Budynku, ul. Nowowiejska 21/25, 00-665 Warszawa; jaroslaw.bigorajski@itc.pw.edu.pl
} 
ły wykonane z ogniw krzemowych. W przypadku krzemowych ogniw fotowoltaicznych absorpcja promieniowania słonecznego powoduje znaczny wzrost temperatury ogniw w wyniku następujących procesów [2], [3]:

- nieaktywnej absorpcji fotonów (niegenerujących par elektron-dziura),

- rekombinacji nośników ładunku poza obszarem złącza p-n,

- ciepła Joule'a-Lenza, wydzielanego na rezystancji szeregowej.

Wzrost temperatury modułów fotowoltaicznych powoduje spadek sprawności elektrycznej. To zjawisko ma dwie przyczyny: wzrost amplitudy drgań sieci krystalicznej, utrudniający przepływ nośników ładunków wskutek zmniejszenia ich ruchliwości oraz utratę zdolności rozdzielania fotogenerowanych ładunków przez złącze [4], [5]. Drugi czynnik nie wpływa istotnie na sprawność konwersji dopóki temperatura nie przekroczy $300^{\circ} \mathrm{C}$ (osiągnięcie tak wysokiej temperatury w naszych warunkach klimatycznych nie jest możliwe) [4], [5]. Wzrost temperatury ogniw fotowoltaicznych powoduje spadek sprawności elektrycznej o 0,4 $0,5 \% / \mathrm{K}$ w przypadku modułów z krzemu polikrystalicznego oraz o $0,2 \% / \mathrm{K}$ w przypadku modułów z krzemu amorficznego [6]. Jedną z metod, która pozwala na rozwiązanie problemu spadku sprawności ogniw fotowoltaicznych wraz ze wzrostem ich temperatury jest integracja tradycyjnych kolektorów słonecznych fototermicznych z modułami fotowoltaicznymi - ang. photovoltaic thermal PVT [5], [6]. Pod modułami fotowoltaicznymi przepuszcza się czynnik (zazwyczaj woda lub powietrze) odbierający od nich ciepło (analogicznie jak w kolektorach słonecznych). Taki zabieg pozwala na obniżenie temperatury pracy ogniw fotowoltaicznych oraz zachowanie stosunkowo wysokiej sprawności ogniw fotowoltaicznych. Uzyskane dodatkowo ciepło można wykorzystać np. do wstępnego podgrzewania ciepłej wody użytkowej. Względny wzrost sprawności elektrycznej dzięki chłodzeniu ogniw fotowoltaicznych może wynosić nawet do $20 \%$ [7]. W dalszej części pracy opisano model matematyczny, który został wykorzystany do przeprowadzenia symulacji komputerowej działania hybrydowej mikroinstalacji słonecznej.

\section{Model matematyczny}

Jako wejściowe dane meteorologiczne dla Warszawy wykorzystano temperaturę powietrza zewnętrznego, napromieniowanie całkowite i jego składowe. Wykorzystane dane to dane godzinowe dla uśrednionego roku (wyliczone na podstawie danych wieloletnich) [8]. Do określania napromieniowania słonecznego docierającego do modułów PVT wykorzystano model izotropowy promieniowania słonecznego dyfuzyjnego (model Liu-Jordana). Zgodnie z teorią LiuJordana godzinne napromieniowanie słoneczne $I_{c}$ docierające na powierzchnię odbiornika pochyloną pod kątem $\beta$ do poziomu zawiera trzy składowe [9]:

- promieniowanie bezpośrednie,

- promieniowanie rozproszone,

- promieniowanie odbite od otoczenia. 
Równanie opisujące napromieniowanie słoneczne $I_{c}$ docierające na powierzchnię odbiornika pochyloną pod kątem $\beta$ do poziomu ma następującą postać, [9]:

$$
I_{c}(t)=I_{b}(t) R_{b}(t)+I_{d}(t) R_{d}+\left(I_{b}(t)+I_{d}(t)\right) \rho_{o} R_{o}
$$

gdzie: $t$ - czas, [s]

$I_{b}(t)$ - napromieniowanie godzinne bezpośrednie, $\left[\mathrm{J} / \mathrm{m}^{2}\right]$;

$I_{d}(t)$ - napromieniowanie godzinne dyfuzyjne, $\left[\mathrm{J} / \mathrm{m}^{2}\right]$;

$R_{b}(t)$ - współczynnik korekcyjny dla promieniowania bezpośredniego, [-];

$R_{d}$ - współczynnik korekcyjny dla promieniowania rozproszonego, [-];

$\rho_{o}$ - refleksyjność podłoża, [-];

$R_{o}$ - współczynnik korekcyjny dla promieniowania odbitego, [-].

W obliczeniach zastosowano uproszczony model matematyczny modułów PVT. Dla uproszczenia przeprowadzonej analizy przyjęto, że średnia temperatura modułów PVT - $T_{P V T}$ jest równa średniej temperaturze czynnika chłodzącego moduł [5], [10], [11]. Sprawność modułów fotowoltaicznych została opisana następującą zależnością, [10]:

$$
\eta_{e l}(t)=\eta_{r e f}\left(1-B_{r e f}\left(T_{P V T}(t)-T_{r e f}\right)\right)
$$

gdzie: $\eta_{e l}(t)$ - sprawność elektryczna modułu fotowoltaicznego, [-];

$\eta_{\text {ref }}$ - sprawność elektryczna modułu fotowoltaicznego w warunkach standardowych, [-];

$B_{\text {ref }}$ - temperaturowy współczynnik spadku sprawności, [1/K];

$T_{P V T}(t)$ - temperatura modułu PVT, [K];

$T_{\text {ref }}$ - temperatura referencyjna modułu PVT, [K].

Moc elektryczna modułów PVT wyznaczana była z następującej zależności:

$$
Q_{e l}(t)=\eta_{e l}(t) \cdot A_{P V T} \cdot \frac{I_{c}(t)}{\Delta t}
$$

gdzie: $Q_{e l}(t)$ - moc elektryczna modułów, [W];

$A_{P V T}$ - powierzchnia modułów fotowoltaicznych, $\left[\mathrm{m}^{2}\right]$;

$\Delta t=3600 \mathrm{~s}-$ krok czasowy wykorzystywany podczas obliczeń, [s]. 
Podczas wyliczania mocy elektrycznej instalacji PVT dodatkowo uwzględniono średnioroczną sprawność falownika oraz przewodów DC i AC, [12]. Sprawność termiczna modułów PVT została określona zgodnie z rozszerzonym modelem Hottella -Whilliera-Blissa następująco, [13]:

$$
\eta_{t h}=F_{R}\left[(\tau \alpha)\left(1-\eta_{e l}(t)\right)-U_{L}\left(\frac{T_{i n}(t)-T_{a}(t)}{\frac{I_{c}(t)}{\Delta t}}\right)\right]
$$

gdzie: $\quad F_{R}-$ współczynnik odprowadzenia ciepła z kolektora, [-];

$\tau \alpha$ - współczynnik transmisyjno-absorpcyjny, [-];

$U_{L}$ - współczynnik strat ciepła, $\left[\mathrm{W} /\left(\mathrm{m}^{2} \mathrm{~K}\right)\right]$;

$T_{\text {in }}(t)$ - temperatura cieczy na wejściu do kolektora, $[\mathrm{K}]$;

$T_{a}(t)$ - temperatura powietrza atmosferycznego, $[\mathrm{K}]$.

Moc cieplna użyteczna uzyskiwana z modułów PVT była określana następująco:

$$
Q_{u}(t)=\eta_{t h} \cdot A_{P V T} \cdot \frac{I_{c}(t)}{\Delta t}
$$

gdzie: $Q_{u}(t)$ - moc cieplna użyteczna, [W];

$A_{P V T}$ - powierzchnia modułów PVT, $\left[\mathrm{m}^{2}\right]$;

$\eta_{t h}$ - sprawność termiczna, [-];

Założono, że ciepło jest odzyskiwane z całej powierzchni modułów PVT. Zbiornik magazynujący jest zbiornikiem z pełnym mieszaniem, tzn. temperatura $T_{s}$ czynnika magazynującego $\mathrm{w}$ danej chwili czasu $t$ jest jednakowa w całej objętości zbiornika. Założono, że zużycie energii przez dodatkowe urządzenie mieszające jest na tyle niewielkie, że można je pominąć w bilansie energetycznym zbiornika. Zgodnie z powyższymi założeniami bilans energii zbiornika magazynującego w danej chwili $t$ można zapisać jako równanie różniczkowe następującej postaci, [9]:

$$
\left(\rho \cdot c_{w} \cdot V\right) \frac{d T_{s}}{d t}=Q_{\text {in }}(t)-Q_{\text {out }}(t)
$$

gdzie: $\rho$ - gęstość wody, $\left[\mathrm{kg} / \mathrm{m}^{3}\right]$;

$c_{w}$ - ciepło właściwe wody, $[\mathrm{J} /(\mathrm{kgK})]$;

$V$ - objętość zasobnika, $\left[\mathrm{m}^{3}\right]$; 
$Q_{i n}(t)$ - moc cieplna dostarczana do zbiornika magazynującego, [W];

$Q_{\text {out }}(t)$ - moc cieplna pobierana ze zbiornika magazynującego, [W].

Wszystkie obliczenia przeprowadzono $\mathrm{z}$ przedziałem czasowym $\Delta t=3600$ s. Po scałkowaniu równanie (6) zapisano następująco:

$$
T_{s}^{t+1}=T_{s}^{t}+\frac{\Delta t}{V \rho c_{w}}\left[Q_{i n}^{t}(t)-Q_{\text {out }}^{t}(t)\right]
$$

Równanie (7) określa temperaturę magazynowania po czasie $\Delta$ t. Dodatkowo założono, że temperatura magazynowania $T_{s}$ nie może osiągnąć wartości mniejszej niż wartość minimalnej temperatury magazynowania $T_{\text {min }}$ oraz wartości większej niż wartość maksymalnej temperatury magazynowania $T_{\max }$. Gdy temperatura magazynowania jest wyższa lub równa wymaganej temperaturze c.w.u. $T_{c w u}$, wtedy woda jest pobierana bezpośrednio ze zbiornika magazynującego, który jest uzupełniany zimną wodą wodociągową o temperaturze $T_{m i n}$. W przypadku, gdy woda w zbiorniku magazynującym ma temperaturę niższą niż $T_{c w u}$, wtedy woda również jest pobierana ze zbiornika ale dodatkowo jest jeszcze podgrzewana konwencjonalnym podgrzewaczem, tak aby uzyskać wymaganą temperaturę.

\section{Analiza wyników}

W tabeli 1 zestawione zostały wybrane wartości parametrów wykorzystanych do przeprowadzenia symulacji komputerowej funkcjonowania hybrydowej mikroinstalacji słonecznej.

Rozważana instalacja PVT ma moc $2 \mathrm{kWp}$, co odpowiada powierzchni modułów równej $13 \mathrm{~m}^{2}$. Rozważano moduł hybrydowy PVT bez osłony. W sy-

Tabela 1. Wartości wybranych parametrów wykorzystanych podczas analizy

Table 1. The selected parameter values used in the analysis

\begin{tabular}{|c|c|c|c|c|}
\hline Lp. & Symbol & Opis & Wartość & Źródło \\
\hline 1. & $\eta_{\text {ref }}$ & $\begin{array}{l}\text { sprawność elektryczna modułu fotowolta- } \\
\text { icznego w warunkach standardowych [-] }\end{array}$ & 0,127 & \multirow{2}{*}[10]{} \\
\hline 2. & $B_{r e f}$ & $\begin{array}{l}\text { temperaturowy } \\
\text { sprawności [-] }\end{array}$ & 0,0063 & \\
\hline 3. & $A_{P V T}$ & powierzchnia modułów PVT $\left[\mathrm{m}^{2}\right]$ & 13 & - \\
\hline 4. & $A_{P V}$ & powierzchnia modułów PV $\left[\mathrm{m}^{2}\right]$ & 13 & - \\
\hline 5. & $F_{r}$ & współczynnik odprowadzenia ciepła [-] & 0,6 & \multirow{3}{*}{ [13] } \\
\hline 6. & $U_{L}$ & współczynnik strat ciepła, $\left[\mathrm{W} /\left(\mathrm{m}^{2} \mathrm{~K}\right)\right]$ & 22 & \\
\hline 7. & $\tau \alpha$ & współczynnik transmisyjno-absorpcyjny, [-] & 0,78 & \\
\hline 8. & $V$ & objętość zasobnika c.w.u., $\left[\mathrm{m}^{3}\right]$ & 0,4 & - \\
\hline
\end{tabular}


mulacji założono, że moduły są skierowane na południe i pochylone pod kątem 45 stopni do poziomu. Moduły nie są zacieniane. Założono, że instalacja pracuje na potrzeby budynku jednorodzinnego zlokalizowane w Warszawie.

$\mathrm{Na}$ rysunku 1 zaprezentowane zostały dzienne zmiany temperatury modułów fotowoltaicznych oraz sprawności elektryczne, w dniu 6 czerwca, w przypadku instalacji PVT oraz w przypadku analogicznej instalacji PV (bez chłodzenia modułów). Można zaobserwować, że zastosowanie chłodzenia modułów w przypadku instalacji PVT pozwala na znaczne obniżenie wartości osiąganych temperatur, co bezpośrednio przekłada się na zachowanie wyższych wartości sprawności elektrycznej. To z kolei pozwala na zwiększenie produkcji energii elektrycznej. W rozważanej instalacji PVT roczna produkcja energii elektrycznej wynosi $1714 \mathrm{kWh} /$ rok, a w standardowej analogicznej instalacji PV $1502 \mathrm{kWh} /$ rok. Dodatkową korzyścią z zastosowania instalacji PVT jest ciepło pozyskane z instalacji. Ciepło to jest wykorzystywane do wstępnego podgrzewania c.w.u. Z przeprowadzonej analizy wynika, że roczny uzysk ciepła z instalacji PVT wynosi $2359 \mathrm{kWh} /$ rok $\left(181 \mathrm{kWh} / \mathrm{m}^{2} /\right.$ rok $)$.

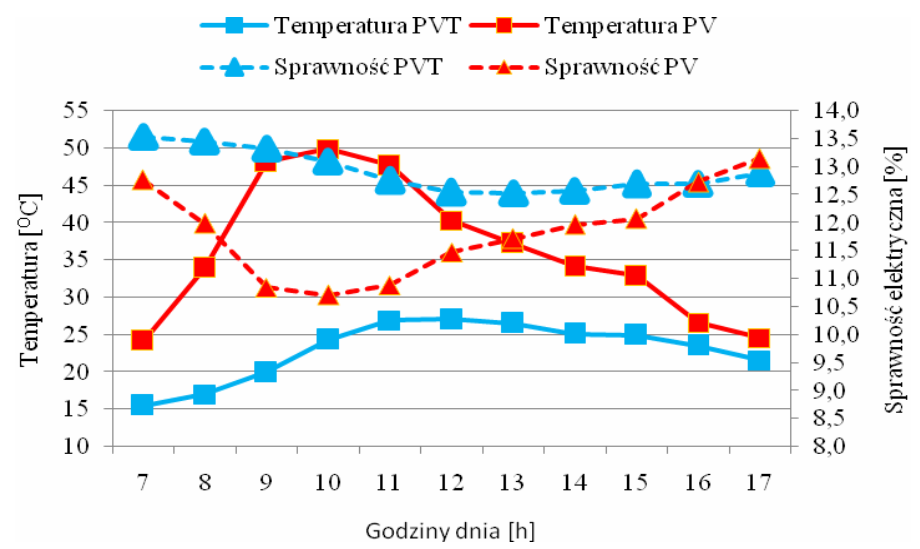

Rys. 1. Dzienny przebieg temperatury oraz sprawności elektrycznej instalacji PV oraz PVT

Fig. 1. Daily course of temperature and electrical performance of PV and PVT installation

W uproszczonej analizie ekonomicznej założono, że porównujemy instalację PVT z sytuacją, w której cała energia elektryczna jest kupowana z sieci elektroenergetycznej, a c.w.u. przygotowywana jest przy pomocy elektrycznego podgrzewacza. Dodatkowo założono, że zużycie w rozważanym obiekcie jest na tyle duże, że całą wyprodukowana energia elektryczna jest zużywana na bieżąco. W przypadku instalacji PVT daje to oszczędność wynoszącą 1396 PLN/rok (przy założeniu ceny energii elektrycznej 0,60 PLN/kWh). Biorąc pod uwagę, że koszt rozważanej instalacji PVT został oszacowany na 22000 PLN [14] to prosty okres zwrotu rozważanej instalacji wynosi około 16 lat. 


\section{Wnioski}

Z przeprowadzonej analizy wynika, że zastosowanie modułów PVT pozwala na znaczne ograniczenie temperatur modułów, co pozwala na utrzymanie wyższych sprawności elektrycznych oraz uzyskanie dodatkowego ciepła użytecznego. Koszty inwestycyjne związane z instalacją PVT są stosunkowo wysokie i nie pozwalają na uzyskanie zadowalających okresów zwrotu nakładów inwestycyjnych. Celowym wydaje się zastosowanie wsparcia finansowego dla tego typu instalacji, aż do momentu gdy efekt skali oraz powszechność tego typu instalacji spowoduje spadek kosztów, a co za tym idzie większą opłacalność inwestycji.

\section{Literatura}

[1] Bai A., Popp J., Balogh P., Gabnai Z., Palyi B., Farkas I., Pinter G., Zsiboracs: Technical and economic effects of cooling of monocrystalline photovoltaic modules under Hungarian conditions, Renewable and Sustainable Energy Reviews, Volume 60, 2016, 1086-1099.

[2] Radziemska E.: Thermal performance of Si and GaAs based solar cells and modules: a review. Progr. Energy Combust. Sci., 2003, 29, 407-424.

[3] Tripanagnostopoulos Y.: Aspects and improvements of hybrid photovoltaic/thermal solar energy systems, Solar Energy 81, 2007, 1117-1131.

[4] Lewandowski W.M.: Proekologiczne odnawialne źródła energii, Wydawnictwo WNT, Warszawa 2012.

[5] Bigorajski J. Chwieduk D.: Systemy hybrydowe fotowoltaiczno-termicznosłoneczne, w: Wybrane problemy techniki Dzięgielewski Andrzej, Szychowski Dariusz, Wernik Jacek ( red.), 2015, 269-279.

[6] Tripanagnostopoulos Y. (2012), Photovoltaic/Thermal Solar Collectors, In: Comprehensive Renewable Energy, Volume 3.

[7] Olchowik J.M. i in.: Comparative analysis of solar cells efficiency in stationary and navigated hybrid systems under southeast Poland conditions, Photovoltaic Energy Conversion, 2006 IEEE 2006 Proc. of 4th World Conference on Photovol taic Energy Conversion, Waikoloa, Hawaii, 7-12 maja 2006.

[8] Strona internetowa Ministerstwa Infrastruktury i Budownictwa, http://mib.gov.pl/2Wskazniki_emisji_wartosci_opalowe_paliwa.htm\#, data dostępu: 18.05.2016.

[9] Chwieduk D. (2011), Energetyka stoneczna budynku, Wydawnictwo "Arkady", Warszawa.

[10] Skoplaki E., Palyvos J.A., Operating temperature of photovoltaic modules: A survey of pertinent correlations, Renewable energy 34, 2009, 23-29.

[11] Moharram K.A., Abd-Elhady M.S., Kandil H.A., El-Sherif H.: Enhancing the performance of photovoltaic panels by water cooling, Ain Shams Engineering Journal 2013, 4, 869-877.

[12] Piątek W.: Ekonomika różnych instalacji PV, Ośrodek Szkoleniowo-Badawczy w Zakresie Energii Odnawialnej w Ostoi, Zachodniopomorski Uniwersytet Technologiczny w Szczecinie, 2014. 
[13] Anderson T.N., Duke M., Morrison G.L., Carson J.K. (2009), Performance of a building integrated photovoltaic/thermal (BIPVT) solar collector, Solar Energy, str. 445-455.

[14] Chwieduk Dorota, Bigorajski Jarosław, Michał Chwieduk: Narzędzie użytkowe wymiarowania $i$ symulacji funkcjonowania słonecznych systemów grzewczych w warunkach krajowych, w: Instal, Ośrodek Informacji "Technika instalacyjna w budownictwie", nr 12, 2013, ss. 39-42.

\section{TECHNICAL AND ECONOMIC ANALYSIS OF HYBRID SOLAR MICROINSTALLATION}

\section{S u m m a r y}

The article is devoted to the analysis of hybrid solar installation. Article applies both to the production of electricity and heat from solar radiation. The biggest problem associated with the generation of electricity from solar energy is relatively low efficiency of photovoltaic cells currently available. Most of the absorbed solar energy is converted to heat, which is lost to the environment. This heat raises the temperature of photovoltaic cells. Photovoltaic cells have the property that the higher the temperature, the lower achieve efficiency. To solve this problem we can receive heat from the photovoltaic cells - such a solution is called a photovoltaic thermal - PVT.

The article describes the model of solar radiation and the model of the installation concerned. As input data were used: the ambient temperature, the total irradiation and its components. Semispherical radiation intensity incident on the plane of the receiver of the orientation and the inclination was determined by the model of isotropic diffuse solar radiation (model Liu-Jordan). To model hybrid PVT collector was used a modified model Hottel-Whillier-Bliss. The analysis shows that the installation of PVT with the power of $2 \mathrm{kWp}$ can produce $1714 \mathrm{kWh}$ of electricity per year and $2359 \mathrm{kWh}$ of heat per year. Results presented in this paper show that hybrid systems PVT can be effectively used in domestic conditions, but payback period time is quite long (16 years).

Keywords: renewable energy sources, solar energy, photovoltaic, hybrid installations

DOI:10.7862/rb.2016.182

Przestano do redakcji: $30.06 .2016 r$.

Przyjęto do druku: 30.11.2016 r. 